KATARZYNA KANIOWSKA

Uniwersytet Łódzki

Wydział Filozoficzno-Historyczny

Instytut Etnologii i Antropologii Kulturowej

\title{
PROJEKT ANTROPOLOGII WRAŻLIWEJ. DOŚWIADCZENIE, NARRACJA I ZAANGAŻOWANIE W „SPOŁECZNOŚCI WIEJSKIEJ” K. ZAWISTOWICZ-ADAMSKIEJ
}

W aktualnych dyskusjach o tożsamości antropologii podkreśla się często, że pośród cech wyróżniających naszą dyscyplinę wymieniać trzeba między innymi dwie szczególnie ważne, decydujące o specyfice antropologicznego poznania. Po pierwsze, podstawą dla tegoż poznania są narracje o kulturowej rzeczywistości. Po drugie zaś, w procesie poznania ujawnia się uwikłanie obu podmiotów - badanego i badacza - w przedstawianą rzeczywistość. Uczestnictwo antropologa w badanym przez niego świecie, doświadczanie rzeczywistości i opisywanie jej, konieczność łączenia interpretacji badanych z interpretacją badacza, postrzegane są jako nieodłączne elementy procesu budowania wiedzy w antropologii. Z tych względów w antropologicznej autorefleksji musiało pojawić się pytanie o granice dzielące poznanie naukowe od wiedzy płynącej z doświadczania świata. Pytanie to z kolei (choć, oczywiście, nie ono jedynie) przyczyniło się do wyodrębnienia się nurtu nazwanego antropologia zaangażowaną. Warto jednak zwrócić uwagę na to, że zarówno niektóre problemy antropologii zaangażowanej, jak i antropologii narratywistycznej były przedmiotem wcześniejszego namysłu antropologów, także polskich. Widać to wyraźnie w pracach Kazimiery Zawistowicz-Adamskiej. Jej koncepcja etnografii i główne przedsięwzięcia badawcze pokazują, że niektóre problemy nurtujące współczesną antropologię wcale nie są nowe; że pytania o kwestie epistemologiczne interesowały antropologów od dawna. 
Dorobek naukowy Kazimiery Zawistowicz-Adamskiej po latach znów budzi zainteresowanie. Można ten fakt tłumaczyć rozmaicie - powrotem do rodzimej tradycji etnograficznych badań, chęcią znalezienia pokrewieństwa pomiędzy współczesnymi trendami a wcześniejszymi koncepcjami wypracowanymi w naukach społecznych czy też chęcią odkrywania na nowo wartości polskiej refleksji humanistycznej, szczególnie z okresu międzywojennego. Oczytani we współczesnej światowej literaturze i obeznani z rozmaitymi prądami intelektualnymi, kształtującymi nasze myślenie o zjawiskach i procesach społecznych, świadomi mnóstwa problemów metodologicznych związanych z każdą próbą ich poznania, dostrzegamy coraz częściej, że pewnych wartościowych podpowiedzi szukać możemy w dorobku wielkich, a zapomnianych na długi czas, poprzedników. Nie jest tu moim zamiarem dociekać przyczyn owego odwrotu od dzieł, które w istocie ukształtowały nasze filozoficzne i socjologiczne myślenie. Chcę jedynie podkreślić fakt, iż coraz chętniej - jak mi się wydaje - sięgamy do dorobku naukowego klasyków polskiej humanistyki, widząc w nim wiele wątków, które pozwalają znajdywać inspiracje lub podpowiedzi do rozwiązywania współczesnych dylematów teoretycznych i metodologicznych. Czytanie powtórne prac St. Ossowskiego, L. Flecka, S. Czarnowskiego, M. Ossowskiej, J. St. Bystronia, J. Obrębskiego - by wymienić tu tych jedynie z grona ważnych postaci polskiej humanistyki - pokazuje niejednokrotnie rzeczywistą wartość ich naukowych dokonań, która widziana z perspektywy późniejszej naukowej refleksji, okazuje się wartością większą niż przypisywana im wcześniej.

W polskiej antropologii w ciągu kilku ostatnich lat daje się zaobserwować wzrastające zainteresowanie problemami związanymi z pracą terenową. Badania terenowe uznajemy bezsprzecznie za wyróżnik dyscypliny, a nawet za cechę podstawową jej tożsamości. Przejęta od C. Geertza pewność co do tego, iż antropologię różni od wszystkich innych dyscyplin zajmujących się badaniem kultury „»metoda“ etnograficznych badań terenowych"1, sprawia, że niejako tym bardziej, stając wobec różnorodności antropologicznych koncepcji, uznajemy teren za wspólne i konieczne pole działania antropologa. Nie oznacza to jednak przyjęcia jakiś jednych, obowiązujących ustaleń. Przeciwnie - właśnie ze względu na zróżnicowanie myślenia o antropologii

${ }^{1}$ C. Geertz, Zastane światło. Antropologiczne refleksje na tematy filozoficzne, tłum. Z. Pucek, Universitas, Kraków 2003, s. 119. 
i w antropologii, problem sposobu rozumienia terenu i rozmaitość metod etnograficznych badań znajdują się w centrum prowadzonych współcześnie dyskusji metodologicznych.

W dorobku naukowym K. Zawistowicz-Adamskiej, rozważania o metodach badań pojawiały się albo w pracach odnoszących się do ogólniejszych kwestii (na przykład - problem zależności pomiędzy metodą a specyfiką przedmiotu badań) ${ }^{2}$, albo w komentarzach do konkretnych przedsięwzięć

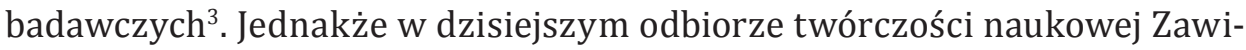
stowicz nie te prace, ale Społeczność wiejskq uważa się za największe i najbardziej inspirujące dokonanie. Prekursorski charakter tej publikacji podkreśla się dziś wielokrotnie. W wydanym niedawno (2011 r.) tomie Wokół Społeczności Wiejskiej. Etnografia Kazimiery Zawistowicz-Adamskiej - kontynuacje i inspiracje $e^{4}$ potwierdza to wielu autorów, analizujących różne aspekty relacjonowanych w Społeczności... badań w Zaborowie.

W moim przekonaniu, Społeczność wiejska czytana dzisiaj pozwala odkrywać wiele takich kwestii, które pojawiły się później w debatach o etnografii czy terenie i to częstokroć - co paradoksalne - w literaturze anglosaskiej, kształtującej współczesną debatę metodologiczną w antropologii i najchętniej uznawaną u nas za źródło inspiracji.

W niniejszych rozważaniach chcę zwrócić uwagę na dwie sprawy, do poruszenia których w moim przekonaniu uprawnia krytyczna lektura tej książki. Od razu tu zaznaczam, iż krytyczne czytanie jakiegokolwiek dzieła naukowego oznacza dla mnie analizowanie jego treści poprzez aktualny stan wiedzy o danym, poruszanym w nim problemie lub/i przez pryzmat aktualnie toczących się dyskusji teoretycznych czy metodologicznych. Obie interesujące mnie kwestie sprowadzić można, przy pewnym uproszczeniu, do dwóch pytań - czy istnieje kobieca narracja antropologiczna oraz czy istnieje związek pomiędzy sposobem narracji a etycznym usposobieniem antropologa, jej autora?

${ }^{2}$ K. Zawistowicz-Adamska, Konkret i kontekst w badaniach etnograficznych, [w:] Zmiany kultury chłopskiej. Problematyka i metody prac etnograficznych, pod red. A. Kutrzeby-Pojnarowej, Wrocław 1973, s. $9-25$.

${ }^{3}$ K. Zawistowicz-Adamska, Wytyczne do badań etnograficznych prowadzonych przez Katedrę Etnografii UŁ w rejonie bełchatowskim, „Zeszyty Badań Rejonów Uprzemysłowionych” 1963, nr 5, s. 309-319.

${ }^{4}$ Wokół Społeczności Wiejskiej. Etnografia Kazimiery Zawistowicz-Adamskiej - kontynuacje i inspiracje, pod red. G. E. Karpińskiej i A. Nadolskiej-Styczyńskiej, „Łódzkie Studia Etnograficzne", T. L, 2011. 
Sądzę, że Społeczność wiejska była i jest czymś więcej niż tylko relacją z badań terenowych. Takiemu przekonaniu dałam wyraz już wcześniej ${ }^{5}$, pisząc o innowacyjnym charakterze projektu badawczego Zawistowicz i prekursorskim sposobie przestawienia tegoż projektu. Nadal uważam, że Społeczność wiejska odzwierciedla pewien projekt antropologii. Dziś widać to wyraźnie, że niewyrażone wprost intencje Zawistowicz-Adamskiej dały wrezultacie polskiej etnografii nowąjakość, pozostającą takniezwykleblisko w stosunku do współczesnych paradygmatycznych wymogów, stawianych badaniom antropologicznym i pisaniu antropologii. Oba postawione przeze mnie pytania wynikają właśnie z tego, że chcę spojrzeć na Społeczność wiejskq jak na tekst w pewnym sensie założycielski i szukać w nim cech, które odzwierciedlają niektóre elementy owego całościowego projektu antropologicznego. Uzasadnieniem sformułowania tych pytań niech będzie moje przekonanie, że sposób pisania jest sposobem przedstawienia doświadczenia i zawsze zdradza postawę wobec opisywanego świata. Interesuje mnie zatem to, jaki w tym projekcie antropologii przyjęty został sposób wyrażania przeżycia, którym jest antropologiczne doświadczenie.

Formułując pytanie dotyczące narracji przyjętej u Zawistowicz zakładam jeszcze coś więcej - zapytując o to, czy istnieje kobieca narracja antropologiczna przypuszczam jednocześnie, że antropologiczne doświadczenie jest w jakiejś mierze uzależnione też od płci badacza. Zdaje sobie sprawę z tego, że użyte w pytaniu sformułowanie jest kłopotliwe przez to, że przymiotnika „kobiecy” staramy się unikać w dyskursie naukowym. Zastosowanie go niesie ze sobą jakieś wartościowanie; sugeruje jakiś podział. Chcę jednak ponieść ryzyko jego zastosowania, bo w odniesieniu do Społeczności wiejskiej wydaje się mieć uzasadnienie.

Interesuje mnie nie tylko to, że ten typ narracji, jaki znajdujemy w Społeczności..., zdumiewająco wyprzedza swój czas - takie pisanie antropologii upowszechniło się dopiero po Writing culture ${ }^{6}$. Samo to, oczywiście, nie tłumaczyłoby mojej sugestii. Chcę raczej wskazać, że narracja zastosowana przez Zawistowicz charakteryzuje się pewnymi cechami, które później odnajdujemy w tekstach wielu antropolożek, opisujących i interpretujących

${ }^{5}$ K. Kaniowska, Społeczność wiejska czytana dzisiaj, [w:] Wokół Społeczności Wiejskiej. Etnografia Kazimiery Zawistowicz-Adamskiej - kontynuacje i inspiracje, pod red. G. E. Karpińskiej i A. Nadolskiej-Styczyńskiej, „Łódzkie Studia Etnograficzne”, T. L, 2011, s. 117-131.

${ }^{6}$ Writing Culture, pod red. J. Clifforda i G. E. Marcusa, University of California Press, Berkeley -Los Angeles-London 1986. 
badaną rzeczywistość z włączeniem swojego własnego doświadczenia tej rzeczywistości. Te cechy, które w moim przekonaniu widać w antropologii pisanej przez kobiety, to m.in. nasycone emocjonalnością dokumentowanie przeżycia, refleksyjność czy wrażliwość (często jawnie obecna w narracji lub otwarcie deklarowana). Zdaję sobie sprawę z tego, że antropologia tak nacechowana ma proweniencje Diltheyowskie i niezależnie od tego, czy rzeczywiście świadomie badacze przyznają się do tego pokrewieństwa, utrwalił się już współcześnie w naszej dyscyplinie sposób pisania, który z zamierzenia daleki jest od wcześniejszego wzorca naukowego opisu. Jasne jest też dla mnie, że ów nowy sposób pisania etnografii nie został przyjęty jedynie przez antropolożki. Mamy co najmniej kilka znakomitych przykładów tego typu pisarstwa antropologicznego autorstwa P. Rabinowa, M. Griaule’a czy innych. Jednakże warto zwrócić uwagę na to, że jest on stosowany częściej przez badaczki uprawiające antropologię, jak również na fakt zdominowania antropologii zaangażowanej przez kobiety. Być może więc uprawnione jest połączenie narracji o wymienionych wyżej cechach z tym akurat typem antropologii. To dawałoby jeszcze inną możliwość czytania Społeczności wiejskiej - można by widzieć w niej wczesny przykład antropologii zaangażowanej. Wiele fragmentów z opisu badań zaborowskich, jak i wiele uwag czy komentarzy Zawistowicz, zamieszczonych na kartach Społeczności... pozwala, jak sądzę, podtrzymać tę tezę. Poglądy Zawistowicz zbieżne są z wieloma założeniami, które współcześnie uznaje się za fundamentalne dla antropologii doświadczenia, antropologii w działaniu czy innych nurtów antropologii zaangażowanej. Kilka dowodów na tę zbieżność warto tu przytoczyć.

Hana Cervinkova i Bogusława Gołębniak we wstępie do Badań w działaniu. Pedagogiki i antropologii zaangażowanych ${ }^{7}$ przypominają stanowisko Johna Bennetta, który:

...dokonuje porównania dwóch form praktycznie zorientowanych podejść - antropologii w działaniu i antropologii stosowanej. Pierwsze z nich - inspirowane pracą Sola Taxa - rozwijane współcześnie także pod takimi nazwami jak antropologia zaangażowana czy antropologia radykalna, odróżnia od klasycznych aplikacji podejmowanych w tzw. badaniach stosowanych to, że badacze działają tu z ludźmi i na rzecz ludzi, a nie w interesie instytucji czy podmiotów zlecających badania ${ }^{8}$.

${ }^{7}$ Badania w działaniu. Pedagogika i antropologia zaangażowane, pod red. H. Cervikovej i B. D. Gołębniaka, Wydawnictwo Naukowe Dolnośląskiej Szkoły Wyższej, Wrocław 2010.

${ }^{8}$ Tamże, s. XI. 
Tak właśnie działa w Zaborowie Zawistowicz; jest ze swymi badanymi emocjonalnie związana, a to każe jej uczestniczyć, a nawet kierować niektórymi ich działaniami. Jest więc wrażliwym badaczem jednocześnie realizującym ideały działaczki społecznej, ukształtowanej przez międzywojenny, inteligencki etos.

Projekt etnografii i związany z nim sposób jej pisania, jaki znajdujemy w Społeczności wiejskiej współbrzmi także znakomicie z deklaracjami i postawą Kirsten Hastrup. W Drodze do antropologii... ${ }^{9}$ Hastrup pisze:

moja teza brzmi, że performatywny paradoks antropologii implikuje pogodzenie ze sobą obiektywności i solidarności. Jak zauważył Richard Rorty, solidarności nie odkrywa się za pomocą refleksji, lecz stwarza poprzez wyobraźnię, która uwrażliwia nas na życie obcych nam ludzi. Antropologiczna wrażliwość na obce sposoby życia i myślenia utrudnia zepchnięcie tej kwestii na margines. »Ten proces stopniowego dostrzegania w innych istotach ludzkich nie ,ich', lecz, jednych z nas' polega na szczegółowym opisywaniu, jacy są obcy nam ludzie, przy jednoczesnym określaniu na nowo nas samych «. To niewątpliwie jest zadanie dla etnografii - program, który opiera się na głęboko moralnych podstawach, nawet jeśli samo zadanie ma charakter teoretyczny ${ }^{10}$.

Stanowisko duńskiej antropolożki, sformułowane współcześnie, z punktu widzenia bliskich nam dzisiaj paradygmatycznych założeń, charakteryzuje w pełni postawę badawczą i przekonania Zawistowicz-Adamskiej. W relacji z badań w Zaborowie obcy przedstawiani są jako „jedni z nas” - owszem, żyją w innych realiach, inny jest kontekst ich działań i postaw, ale antropolog może i ma obowiązek przedstawić ich świat i ich samych solidaryzując się z nimi, do czego konieczne są mu wyobraźnia i wrażliwość. W narracji antropologicznej przyjętej w Społeczności wiejskiej bez trudu odnajdujemy świadectwa owej „głęboko moralnej podstawy” (czasem tylko postulowanej, czasem faktycznie realizowanej) działań antropologa. W rezultacie, relacja o badanym świecie, oprócz wartości poznawczych, zyskuje też wartość etyczną - uczy wrażliwego i zaangażowanego spojrzenia na obcość, która $\mathrm{w}$ istocie nie istnieje, a jest raczej sprawą określonego kulturowego kontekstu lub przyjętej konwencji. Konfrontując własne doświadczenie z doświadczeniem badanych, Zawistowicz przełamuje dotychczasowe kanony antro-

${ }^{9}$ K. Hastrup, Droga do antropologii. Między doświadczeniem a teoriq, Wydawnictwo Uniwersytetu Jagiellońskiego, Kraków 2008.

10 Tamże, s. 17. Śródcytat: R. Rorty, [wyd. polskie] Przygodność, ironia i solidarność, tłum. W. J. Popowski, Spacja, Warszawa 1996, s. 15. 
pologicznych badań i antropologicznego pisarstwa. Otwarcie pisze o sobie w terenie, w rzeczywistości odmiennej od jej własnej, niemal w równym stopniu interesując się sobą, jak i badanymi. Taka narracja odzwierciedla istotę całego projektu etnografii realizowanego w zaborowskich badaniach. Jednocześnie, co warto podkreślić i czego trzeba być świadomym, ten sposób narracji przyczynia się bezsprzecznie do wzmocnienia siły perswazji. Szczerość relacji i emocjonalność opisu zawsze oddziaływa silniej. Problem związany z takim pisaniem antropologii polega zatem najpewniej na utrzymaniu równowagi pomiędzy - jak ujmuje to Hastrup - obiektywnością a solidarnością. W istocie to sztuka karkołomna, ale czasem się udaje. Jak zauważa Edward M. Bruner:

\begin{abstract}
Trudność nie leży jednak w doświadczeniu terenowym, lecz w używanym do interpretacji danych z terenu aparacie pojęciowym, który zwykle odfiltrowywuje doświadczenie. Co ciekawe, większość dobrych etnografów ożywia swoje opisowe relacje $\mathrm{z}$ terenu, włączając $\mathrm{w}$ nie obrazowe urywki osobistej narracji, elementy biograficzne czy też pełne życia fragmenty z notatek terenowych (...). Skutkiem tego doświadczenie powraca jako składnik opowieści, bardziej jednak jako produkt uboczny niż deklarowany przedmiot badań ${ }^{11}$.
\end{abstract}

U Zawistowicz trudność ta jest rozwiązana radykalnie. Nie ma właściwie w jej narracji miejsca na „aparat pojęciowy”, zatem nie pojawia się w niej nic, co by odfiltrowywało doświadczenie. To ono jest istotą całego przedsięwzięcia etnograficznego. Można by więc powiedzieć, że Społeczność wiejska jest prototypem antropologii doświadczenia. Kobiecy rys tej narracji nadają nie tylko wspomniane wcześniej cechy, pokazujące empatyczny charakter przyjętej postawy badawczej, ale i to, że Zawistowicz pisze o swoim doświadczeniu będąc świadomą, że bycie kobietą utrudnia lub ułatwia jej badania; że ten fakt nie jest obojętny w procesie poznawania i interpretowania badanej rzeczywistości. Widać to wyraźnie szczególnie tam, gdzie opisuje swoje relacje z badanymi - używane często przez zaborowian określenie "pani” czy „nasza pani”, zaznacza nie tylko dystans kulturowy (klasowy?). Tożsamość badaczki określana jest także poprzez płeć. Bycie kobietą ustanawia niejednokrotnie typ relacji z badanymi - na „babę” inaczej reagują, widząc $\mathrm{w}$ jej zachowaniach przypisywane stereotypowo cechy. Widać to $\mathrm{w}$ wielu fragmentach, jak na przykład w takiej scenie:

${ }^{11}$ E. M. Bruner, Przeżycie i jego ekspresje, [w:] Antropologia doświadczenia, pod red. V. W. Turnera, E. M. Brunera, tłum. E. Klekot, A. Szurek, Wydawnictwo Uniwersytetu Jagiellońskiego, Kraków 2011, s. 17. 
- A pani myśli, że ja się pani boję - powiedział wyzywająco kładąc ręce do kieszeni.

- Wcale tak nie myślę.

- Myśli pani, że muszę się pani bać - powtórzył z uporem.

- To ja bym powinna Was się bać, bo Was tu tyle, a ja sama jedna. A przecież nie boję się Was. I cóż by to było, żeby chłop baby się bał - dodałam żartobliwie.

Spojrzał na mnie zaskoczony, aż wreszcie roześmiał się w głos. (...) Poszedł naprzód i otworzył drzwi ${ }^{12}$.

Pisząc zaś o zaborowskich dzieciach Zawistowicz notuje:

Dla wszystkich odnajdywałam w sobie macierzyńską czułość. Niezawodnym dziecięcym instynktem dobrze wiedziały o tym. Garnęły się do mnie z całą serdecznością. (...) A jednak tak mało, tak mało mogłam im pomóc! Nie ylko w trosce o chore dzieci czułam swą bezsilność. Wędrując co dnia po chałupach, poczuwałam się do obowiązku przy każdej sposobności uczyć matki najbardziej podstawowych zasad higieny wobec zdrowych dzieci ${ }^{13}$.

Mówiąc o narracji trzeba wspomnieć o jeszcze jednej sprawie, a mianowicie o języku w niej przyjętym. Należy zatem spojrzeć na to, jak cechy konstytuujące ten rodzaj antropologii doświadczenia, z którym mamy tu do czynienia, oddane są w użytym w Społeczności... języku.

Zawistowicz pisze w pierwszej osobie, używając czasu teraźniejszego do opisu scen i rozmów oraz czasu przeszłego we fragmentach poświęconych charakterystyce zdarzeń, sytuacji czy kontekstów ważnych dla ich zrozumienia. Dzięki temu czytelnik ma wrażenie, że obcuje z wierną dokumentacją doświadczenia badaczki, która jednocześnie komentuje z dystansu własny ogląd badanej rzeczywistości. Narracja uwiarygodniana jest zatem niejako podwójnie - szczerością i otwartością oraz obiektywizowaniem i wyjaśnianiem. Język tej narracji jest także dwojaki - sugestywny i perswazyjny; emocjonalny i neutralny. Nowatorskie jest tu bez wątpienia to, co nadaje tekstowi charakter osobistego dokumentu - relacja z badań staje się relacją z własnego przeżycia. Tym samym opis procesu badawczego staje opisem procesu poznawczego, który obejmuje wszystko, co stało się przedmiotem badań terenowych, doświadczeniem badacza i autorefleksyjnym ich rozpoznaniem. Efekt założonego projektu antropologicznego okazał się niezwykle interesujący. Społeczność wiejska stała się takim tekstem, jakich od antropologii domagał się wiele lat później C. Geertz. Zawistowicz w istocie

${ }^{12}$ K. Zawistowicz-Adamska, Społeczność wiejska. Doświadczenia i rozważania z badań terenowych w Zaborowie, Polski Instytut Służby Społecznej, Łódź 1948, s. 38.

13 Tamże, s. 87. 
zmieszała kilka gatunków, by wyrazić swe doświadczenia i zebrać płynącą z nich wiedzę. Wartość poznawcza tego rodzaju narracji jest niewątpliwa. Jedynym niebezpieczeństwem, którego trzeba być świadomym przy wyborze tego rodzaju pisarstwa antropologicznego, jest możliwa utrata kontroli nad językiem. Chcę tym samym zwrócić uwagę na to, jak trudne to pisarstwo. Wymaga ono od badacza nie tylko uzdolnień literackich, odwagi w odsłanianiu prywatności i chęci otwartego prezentowania swego warsztatu. Emocjonalne, empatyczne opisywanie doświadczenia terenowego stawia piszącego wobec niezwykle skomplikowanego zadania, jakim jest wyważenie subiektywnego sądu, osobistego doświadczenia, własnej oceny. Łatwo przekroczyć cieniutką granicę pomiędzy wrażliwym, tkliwym opisem a ckliwością; czy refleksyjnością a ocenianiem. W niektórych fragmentach Społeczności... ta granica została przekroczona.

Drugą interesującą mnie kwestię ujęłam na początku w formie pytania o to, czy istnieje związek pomiędzy sposobem narracji a etycznym usposobieniem antropologa, autora narracji?

Usposobienie etyczne rozumiem tu jako postawę opartą na przekonaniu o prymacie pewnych wartości nad wszystkimi pozostałymi. Postawa taka odciska się, a czasem nawet organizuje antropologiczne narracje, tak jak i dyskursy naukowe. Mimo, iż jesteśmy świadomi tego, że naukowy opis i naukowe pisarstwo muszą być wolne od wartościowania, nader rzadko spełniamy ten wymóg. Dopuszczenie subiektywności w antropologii częstokroć uniemożliwia utrzymanie neutralności aksjologicznej. Usposobienie etyczne antropologa niejako w oczywisty sposób ujawnia się w antropologii doświadczenia, w rozmaitych nurtach antropologii zaangażowanej.

Jeśli pod tym kątem spojrzeć na Społeczność wiejska, to widać wyraźnie, że etyczny aspekt przyjętego w niej relacjonowania doświadczania badanej rzeczywistości wynika w głównej mierze z przynależności Zawistowicz do określonej formacji intelektualnej i moralnej. W moim przekonaniu, na całym projekcie etnografii, jaki znajdujemy w tym tekście, zaważył inteligencki etos, fundujący określone etyczne usposobienie badaczki. W swej narracji o antropologicznym doświadczeniu, opisie i analizie badanej rzeczywistości kieruje się Zawistowicz wartościami i ideałami dominującymi w sposobach myślenia, postawach, liniach karier zawodowych ludzi wykształconych w zakresie nauk społecznych i humanistycznych w międzywojennej Polsce. Ideał nauki, która ma nie tylko wyjaśniać, ale też przyczyniać się do 
zmiany rzeczywistości na lepsze, widać w tym projekcie etnografii bardzo wyraźnie. Równie wyraźnie daje się to zauważyć w opisywanym działaniu Zawistowicz w terenie. Badania terenowe są koniecznym etapem procesu naukowego poznania, ale też stwarzają możliwość ingerowania w badany świat z intencją kształtowania go wedle nowych, lepszych zasad. Teren jest także przygodą, wyzwaniem przed którym staje się w osamotnieniu, w swej obcości wobec nieznanego środowiska. Etnografia ma tu zarazem pozytywistyczny i romantyczny fundament. Mieszanie gatunków w narracji wydaje się być w tym przypadku konsekwencją mieszania się obu tych tradycji. Ostatecznie to one kształtują usposobienie etyczne Zawistowicz. W wielu fragmentach książki znaleźć można tego potwierdzenia. Oto pierwsze z brzegu przykłady:

Współczucie i życzliwość nakładają obowiązek działania. Obowiązek niesienia pomocy, obowiązek uczynności. Jest to ciężki obowiązek. Bo zakres spraw, jakie wymagają uczynności, jest zaiste ogromny. Gdy się z bliska przyjrzy sprawom wsi, z całą jaskrawością wystąpi z jednej strony potrzeba autorytetu, to znaczy kogoś, kto się stanie autorytetem w rzeczach wielkich i małych, z drugiej zaś strony zupełna bezradność wsiowskich ludzi wobec ważnych posunięć życiowych, wobec haseł ideologicznych i światopoglądowych nowatorstw ${ }^{14}$.

Próbowałam przełamać tę bierność. Miałam takich przyjaciół, chłopców i dziewczęta, którzy przychodzili do mnie na pogawędki,którzy mi powierzali swe codzienne troski, mówili chętnie o swych młodzieńczych zawodach i nieśmiałych marzeniach o lepszej przyszłości. Chciałam w nich rozbudzić twórczą energię, zmusić do jakiegoś działania, wzniecić chęć pokonywania trudności. Róbcie coś! - mówiłam jak najbardziej przekonywująco. - Pókiście młodzi! Póki macie dość sił! Sami starajcie się o to, by życie wasze na lepsze się odmieniło. Uczcie się! Macie książki w Domu Ludowym; uczcie się z nich, jak uprawiać warzywa, jak chować drób, jak używać nawozów sztucznych. Sadźcie drzewa owocowe! Róbcie cokolwiek! Bylebyście nie stali w miejscu! Bylebyście wierzyli, że własnym wysiłkiem zdołacie udoskonalić choć jedną dziedzinę waszej gospodarki! ${ }^{15}$.

Nigdy chyba nie powiedziałam tylu słów jednym tchem. Czuję się zawstydzona własnym uniesieniem. I ogarnia mnie straszliwe zmęczenie. Chcę jak najszybciej znaleźć się w domu. Sama. Deszcz wali w okna, smagany wichurą. Za oknami snuje się szarość. Podchodzę do drzwi. Jest taka ścieżka za obrębem wsi, wzdłuż stodół. Można przemknąć się tamtędy niepostrzeżenie do domu i nie spotkać nikogo. Byle nie widzieć ludzi. Ale to będzie słabość. Trzeba ją przezwyciężyć16

\footnotetext{
14 Tamże, s. 131-132.

15 Tamże, s. 97.

16 Tamże, s. 39.
} 
Jeśli spojrzeć na Społeczność wiejska przykładając do niej dzisiejszą miarę, można by uznać, że mamy do czynienia z próbą połączenia autoetnografii z antropologią zaangażowaną. Pozwalało by to - co wydaje mi się interesujące - widzieć w obu tych nurtach współczesnej antropologii ślad jakiś proweniencji pozytywistyczno-romantycznych. Może etnografia zawsze była i będzie tkwiła pomiędzy misyjnością a konfesyjnością; może taki już los tej dziedziny, wynikający z tego czegoś nieuchwytnego, co pojawia się w wyniku doświadczania badanego świata i prób opisywania tegoż doświadczania.

Jeśli zaś rozpatrywać Społeczność... z ówczesnej perspektywy, tym wyraźniej widać, z jakim projektem etnografii tekst ten ściśle się wiązał. Etnografia ma być - w rozumieniu Zawistowicz - czymś więcej aniżeli opisem jakiegoś stanu rzeczy, podjętym w celu jego udokumentowania i wyjaśnienia. Badania terenowe mają dodatkowe zadanie do spełnienia. Mają stworzyć okazję do ingerowania w badaną rzeczywistość - owszem z pełnym dla niej szacunkiem - w imię jej korekty, modyfikacji, zmiany na lepsze. Etyka badacza, w tym typie etnografii, stawia wyżej wartości takie, jak postęp, dobro wspólne, wyzwolenie jednostki spod zastałych kulturowych uwikłań, prawo do równego traktowania. Jest więc owo usposobienie etyczne wypadkową kilku elementów - ówczesnego ideału nauki, sposobu rozumienia celów nauk społecznych, roli uczonego i wreszcie światopoglądu, w którym wspólnota jest stawiana wyżej niźli osoba. To kształtuje właściwie wszystkie cechy charakterystyczne tej etnografii od celów badawczych, poprzez strategie poznania po relacje badacz - badany. Jest ona całkowicie wpisana w paradygmat naukowego działania, dominujący w międzywojennym okresie historii polskiej humanistyki i nauk społecznych. Warto jednak, jak sądzę, zwrócić uwagę na to, że jakkolwiek paradygmat ten uległ głębokim przemianom, pewne jego echa są nadal słyszalne. Współczesna antropologia wyrasta z innego ideału nauki, dokonała gruntownej przebudowy swej tożsamości, co dało przede wszystkim konsekwencje w metodologii naszej dyscypliny, niemniej - mam wrażenie - że w pracach antropologicznych mieszczących się w nurcie autoetnografii czy antropologii zaangażowanej, można wciąż dostrzegać jakiś rys misyjności, braku równowagi w relacji badacz - badany czy nawet dominacji, władzy. 
Konkludując, skłonna byłabym uznać, że Społeczność wiejska, która jest w mym przekonaniu realizacją określonego, wyprzedzającego swój czas projektu etnografii, pozwala na obydwa postawione przeze mnie pytania odpowiedzieć twierdząco. W tego rodzaju dokumencie pracy antropologa, jakim jest rozprawa K. Zawistowicz-Adamskiej, oba moje założenia nie są bezpodstawne. To projekt etnografii, który będąc swoistym „manifestem ideologicznym” naszej dyscypliny, odsłania też pewne niuanse, znaczące dla procesu poznania. Mam takie przeświadczenie, że gdyby istniał angielski przekład Społeczności wiejskiej, kilku antropologicznych prac nie przyjmowalibyśmy z taką atencją. Mnie samą bardzo by interesowała recenzja Społeczności... autorstwa Kirsten Hastrup.

\section{BIBLIOGRAFIA}

- Badania w działaniu. Pedagogika i antropologia zaangażowane, pod red. H. Cervikovej i B. D. Gołębniaka, Wydawnictwo Naukowe Dolnośląskiej Szkoły Wyższej, Wrocław 2010.

- Bruner E. M., Przeżycie i jego ekspresje, [w:] Antropologia doświadczenia, pod red. V. W. Turnera, E. M. Brunera, tłum. E. Klekot, A. Szurek, Wydawnictwo Uniwersytetu Jagiellońskiego, Kraków 2011.

- Geertz C., Zastane światło. Antropologiczne refleksje na tematy filozoficzne, tłum. Z. Pucek, Universitas, Kraków 2003.

- Hastrup K., Droga do antropologii. Między doświadczeniem a teoriq, Wydawnictwo Uniwersytetu Jagiellońskiego, Kraków 2008.

- Kaniowska K., Społeczność wiejska czytana dzisiaj, [w:] Wokół Społeczności Wiejskiej. Etnografia Kazimiery Zawistowicz-Adamskiej - kontynuacje i inspiracje, pod red. G. E. Karpińskiej i A. Nadolskiej-Styczyńskiej, „,tódzkie Studia Etnograficzne”, T. L, 2011.

- Rorty R., Przygodność, ironia i solidarność, tłum. W. J. Popowski, Spacja, Warszawa 1996.

- Wokół Społeczności Wiejskiej. Etnografia Kazimiery Zawistowicz-Adamskiej-kontynuacje i inspiracje, pod red. G. E. Karpińskiej i A. Nadolskiej-Styczyńskiej, „,tódzkie Studia Etnograficzne", T. L, 2011.

- Writing Culture, pod red. J. Clifforda i G. E. Marcusa, University of California Press, Berkeley-Los Angeles-London 1986.

- Zawistowicz-Adamska K., Konkret i kontekst w badaniach etnograficznych, [w:] Zmiany kultury chłopskiej. Problematyka i metody prac etnograficznych, pod red. A. Kutrzeby -Pojnarowej, Wrocław 1973.

- Zawistowicz-Adamska K., Społeczność wiejska. Doświadczenia i rozważania z badań terenowych w Zaborowie, Polski Insty tut Służby Społecznej, Łódź 1948. 
- Zawistowicz-Adamska K., Wytyczne do badań etnograficznych prowadzonych przez Katedrę Etnografii UŁ w rejonie bełchatowskim, „Zeszyty Badań Rejonów Uprzemysłowionych" 1963, nr 5.

\section{THE PROJECT OF SENSITIVE ANTHROPOLOGY. EXPERIENCE, NARRATION AND INVOLVEMENT in “The RuRAl Community” By K. ZAWistowiCZ-ADAMSKA}

Kazimiera Zawistowicz-Adamskiej's "Village Society" is a renown title in the Polish anthropological literature, its unprecedented character is especially evident to the contemporary reader. It fulfills all the requirements that we lay forward for modern anthropological treatise. "Village Society", is a monography to some extent, not dissimilar to autoethnography and engaged anthropology. It employs an anthropological narration that's been influenced by other literary genres and types of academic discourse.

Having underline its merits and literary value, I'm posing two questions in regards to the piece's particular character. Firstly, can it be used as a flagship example of what we refer to as 'feminine' field anthropology - that is field research which marked by emotionalism, empathy and sensitivity? Secondly, does the anthropologist's ethical stance influence his/hers approach to the studied subject matter and to what extent has it an impact on his/hers willingness to alter the reality encountered?

Ethnography according to Zawistowicz, a scholar formed by the academic ethos and scientific paradigm that was present in the polish interwar humanities, is understanding social phenomena across theory and practice, bonded with a strong public obligation to serve an educational role to the public.

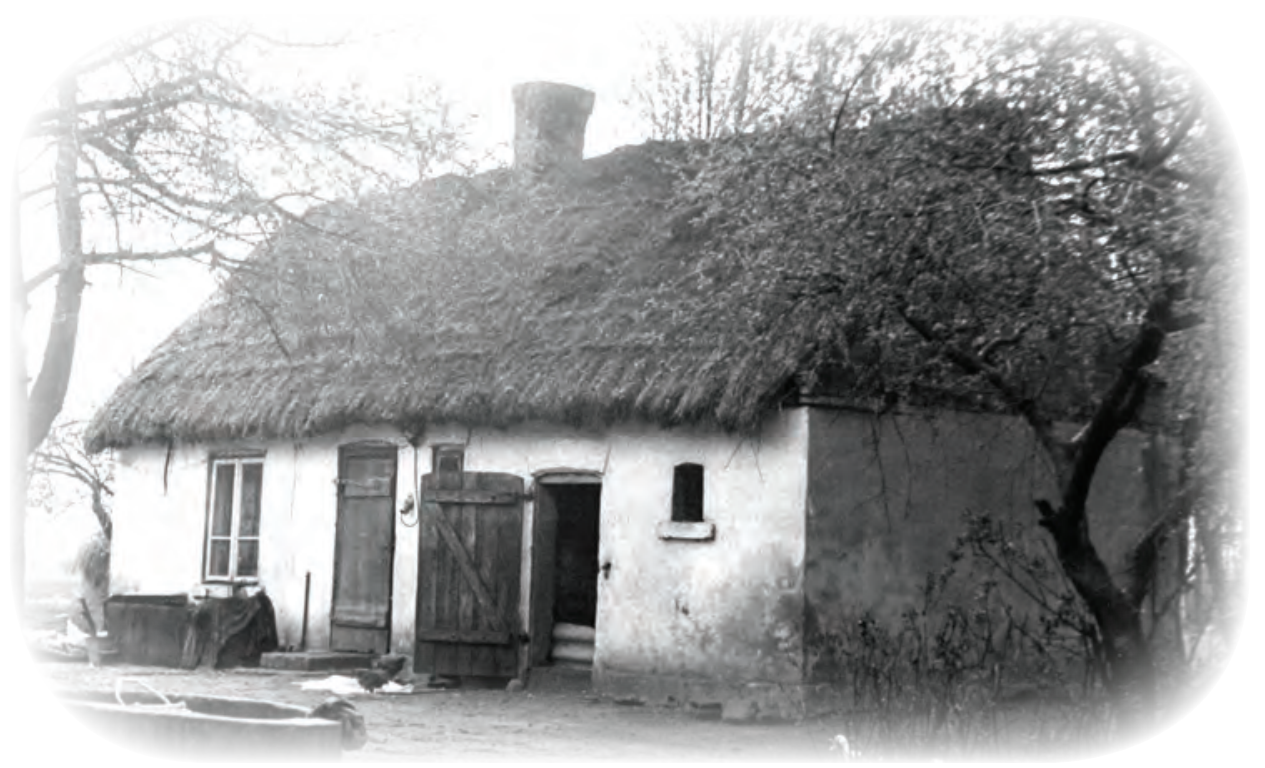

